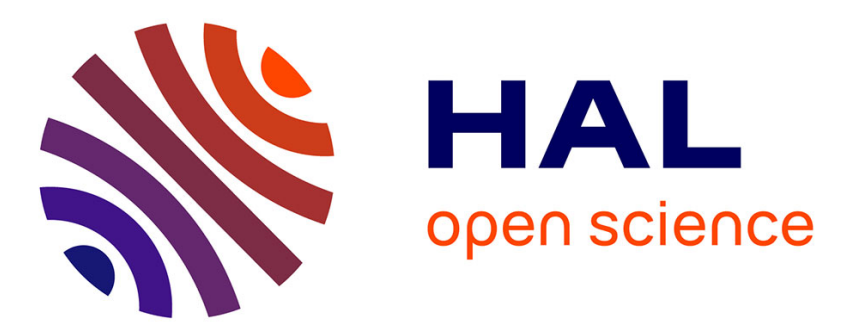

\title{
FLASHLAMP PUMPED COLOR CENTER LASER AT RT
}

D. Mounier, Sébastien Girard, J. Doualan, J. Margerie, K. Mazighi

\section{To cite this version:}

D. Mounier, Sébastien Girard, J. Doualan, J. Margerie, K. Mazighi. FLASHLAMP PUMPED COLOR CENTER LASER AT RT. Journal de Physique IV Proceedings, 1991, 01 (C7), pp.C7-339-C7-341. 10.1051/jp4:1991790 . jpa-00251033

\section{HAL Id: jpa-00251033 https://hal.science/jpa-00251033}

Submitted on 1 Jan 1991

HAL is a multi-disciplinary open access archive for the deposit and dissemination of scientific research documents, whether they are published or not. The documents may come from teaching and research institutions in France or abroad, or from public or private research centers.
L'archive ouverte pluridisciplinaire HAL, est destinée au dépôt et à la diffusion de documents scientifiques de niveau recherche, publiés ou non, émanant des établissements d'enseignement et de recherche français ou étrangers, des laboratoires publics ou privés. 


\section{FLASHLAMP PUMPED COLOR CENTER LASER AT RT}

D. MOUNIER ${ }^{(1)}$, S. GIRARD, J.L. DOUALAN, J. MARGERIE ${ }^{(1)}$ and K. MAZIGHI

Laboratoire de Spectroscopie Atomique (URA 19 CNRS) ISMRa, 6 boulevard Maréchal Juin, F-14050 Caen cedex, France

\section{ABSTRACT}

The color centers can lase at RT of near RT if we use a pulsed pump. We describe a flashlamp color center laser at RT with $\left(\mathrm{F}_{2}{ }^{+}\right)^{*}$ center in $\mathrm{NaF} \mathrm{Mg}{ }^{2+}$ and $\left(\mathrm{F}_{2}^{+}\right)_{\mathrm{H}}$ in $\mathrm{NaCl} \mathrm{OH}$. The lasers are tuned from 1.05 to $1.27 \mu \mathrm{m}$ for $\left(\mathrm{F}_{2}^{+}\right)^{+}$and 1.52 to $1.76 \mu \mathrm{m}$ for $\left(\mathrm{F}_{2}^{+}\right)_{\mathrm{H}^{*}}$. The energy per pulse is few mJ. A RT the output power drops after few $10^{5}$ pulses for $\left(\mathrm{F}_{2}\right)^{*}$ and few $10^{3}$ pulses for $\left(\mathrm{F}_{2}^{+}\right)_{\mathrm{H}}$. If the $\mathrm{NaCl} \mathrm{OH}$ crystal is cooled to $-40^{\circ}$ the $\left(\mathrm{F}_{2}^{+}\right)_{\mathrm{H}}$ laser emission is stable.

Flashlamp pumped laser are interesting for their simple building and their low cost. The flashlamp emission is very broad, it's possible to pump many color centers. For some of them. it's necessary to use 2 wavelengths one for the pump the other one for the reorientation, in the flashlamp there is this 2 wavelengths.

The $\mathrm{NaF} \mathrm{Mg}^{2+}$ crystal are grown by Bridgman technique in a graphite crudible, the doping is $10^{-2} \mathrm{~mol} \%$ of $\mathrm{MgF}_{2}$. The samples are colored by an $\mathrm{e}^{-}$beam $1.5 \mathrm{Mev}$ at $100^{\circ} \mathrm{C}$ between 40 and 70 min with a current of $0.9 \mu \mathrm{A} \mathrm{cm}^{-2}$. The $\mathrm{F}_{2}^{+}$centers appear,when the crystal is warmed up to $R T$, these centers spontaneously transform into $\left(\mathrm{F}_{2}^{+}\right)$centers in few hours in dark. The absorption and emission bands at RT for $\left(\mathrm{F}_{2}^{+}\right)^{*}$ centers in $\mathrm{NaF} \mathrm{Mg}^{2+}$ are $0.85 \mu \mathrm{m}$ and $1.09 \mu \mathrm{m}$ respectively, typically the absorption is $6 \mathrm{~cm}^{-1}$.

For the $\mathrm{NaCl} \mathrm{OH}$ crystal we use the Kyropoulos technique, the $\mathrm{NaCl}$ powder is doped with $\mathrm{NaOH}$ and grown under $\mathrm{Ar}$ atmosphere. The doping is $10^{-2} \mathrm{~mol} \%$ of $\mathrm{OH}^{-}$. The sample is additively colored in sodium vapor at $700^{\circ} \mathrm{C}$ in heat pipe apparatus. During coloration $\mathrm{OH}^{-}$are converted into $\mathrm{O}^{2-}[]$

$$
\mathrm{OH}+2 \mathrm{~F} \rightarrow \mathrm{U}+\mathrm{O}^{2-}[]
$$

Before using the crystal is quenched, the colloid are converted in $\mathrm{F}$ centers. An exposure with $\mathrm{F}$ light $(\approx 500 \mathrm{~nm})$ produces the $\left(\mathrm{F}_{2}{ }^{+}\right)_{\mathrm{H}}$ centers

$$
\mathrm{F}+\mathrm{O}^{2-}[] \underset{\mathrm{RT}}{\stackrel{\mathrm{h} \nu}{\longrightarrow}}\left(\mathrm{F}_{2}^{+}\right)_{\mathrm{H}}
$$

(1) Aussi Université de Caen, UFR de Sciences 
The absorption and emission bands at RT are 1.05 and $1.55 \mu \mathrm{m}$ respectively.

In these experiments we use a circular or parallelepiped rod with approximately $10 \mathrm{~mm}^{2}$ cross-section and a length between 15 and $50 \mathrm{~mm}$. This rod lie along a focal axe of an elliptical-cylindrical reflector. It's fixed to a copper block. A Xe flashlamp is at the other focal axe, it's cooled by a flow of water or other solutions. The pump pulse have between 10 and $20 \mu \mathrm{s}$. FWHM, the repetition rate is up to $2 \mathrm{~Hz}$ and the maximum electrical energy per pulse is $19 \mathrm{~J}$. The laser cavity is limited by a concave gilt mirror ( $1 \mathrm{~m}$ curvature radius) and a plane output mirror . The laser is turned with a prism inside the cavity.

The laser emission has been obtained between RT and $77 \mathrm{~K}$ for $\left(\mathrm{F}_{2}^{+}\right)^{*}$ centers in NaF $\mathrm{Mg}^{2+}{ }^{[1]}$. Here we describe the RT laser emission. With $42 \%$ output coupling mirror the energy per pulse is $9 \mathrm{~mJ}$ for $12 \mathrm{~J}$ pump power. The lower threshold obtained is $0.3 \mathrm{~J}$ for $2 \%$ output coupling. At the threshold the laser emission appears only at the top of the pump pulses. The energy is not stored in the excited state because its lifetime ( $\approx 40 \mathrm{~ns})$ is very small compared with the pump pulses (few $\mu \mathrm{s}$ ). We can consider the pump power at the top of the pump pulse, it's $20 \mathrm{KW}$. This value is very low but it's higher than a cw lamp $(\approx 2 \mathrm{KW})$. If the threshold is reduced by a factor 10 it would be possible to obtain cw laser emission with a lamp pumping. The losses in the cavity are $30 \%$, the reflection on the rod and the transmission or absorption on the mirror give $10 \%$ of losses, the other $20 \%$ are unknown (diffusion, depolarisation,...). If we reduce noticeably the losses the threshold will be improved, but this color center is not a good material for cw lamp pumping because it's known ${ }^{[2]}$ to bleach under high power excitation. Under flashlamp pumping we have measured a fading effect of the laser emission but we can use the rod during few $10^{5}$ pulses before change it. This fading is the same between 77K and RT. With a prism the laser can be tuned between 1.05 and $1.27 \mu \mathrm{m}$.

The $\left(\mathrm{F}_{2}^{+}\right)_{\mathrm{H}}$ centers in $\mathrm{NaCl} \mathrm{OH}$ lase ${ }^{[3]}$ if 2 wavelengths are used one for the pump at $1.06 \mu \mathrm{m}$ and a second one in UV or near $500 \mathrm{~nm}$ for reorientation of the centers. In the spectrum of the flashlamp there is this 2 wavelengths. We have obtained pulse laser emission at RT and at lower temperature ${ }^{[4]}$ with a great part of this spectrum from IR to $360 \mathrm{~nm}$. The output energy is $2.1 \mathrm{~mJ}$ for $10 \mathrm{~J}$ pump energy with $20 \%$ output coupling. The threshold is $0.9 \mathrm{~J}$ for $5 \%$ output coupling, this value is higher than the threshold of the $\left(\mathrm{F}_{2}^{+}\right)^{*}$ center. The $\left(\mathrm{F}_{2}^{*}\right)$ absorption band is near the maximum of the Xe flashlamp emission.

Under polarized pump there is a reorientation of the center and the emission decreases, it's necessary to counter balance this effect for stable emission. An other polarization at the pump wavelength or an other wavelength to pump in an upper excited state stabilise the emission. The flash emission is not polarized, we must see any bleaching effect. With all the spectrum of the flashlamp the laser emission is stable at RT and 77K. If the short wavelength are cut $(<660 \mathrm{~nm})$ there is a quick bleaching at $\mathrm{RT}$ and not at $77 \mathrm{~K}$. The threshold is measured between $77 \mathrm{~K}$ and RT, it's increased quickly around $150 \mathrm{~K}$, the centers are destroyed. There is 2 kinds of $\left(F_{2}^{*}\right)_{\mathrm{H}}$ centers ${ }^{[4]}$ one is stable at $\mathrm{RT}$, the other at $77 \mathrm{~K}$, but the difference in the microscopic structure are not known. Over $150 \mathrm{~K}$ after bleaching if we shine with the UV and visible part of the flashlamp spectrum the laser emission appears again, the centers are regenerated. More experiment will be necessary to understand the kinetic of these centers. This laser is tuned between 1.52 and $1.76 \mu \mathrm{m}$.

Ar R'T we observe a fading effect in laser emission, the output power decrease significatly after 7000 pulses. It's better to work at $\mathrm{O}^{\circ} \mathrm{C}$ the sample can be used during $10^{5}$ pulses. If the crystal is cooled to $-40^{\circ}$ there is no fading effect after $1.510^{5}$ pulses.

The flashlamp laser is easy to use and it's no expensive. With the same laser device and different color centers we have obtained laser emission in a part of the IR spectrum : $\left(\mathrm{F}_{2}\right)_{\mathrm{A}}$ $\mathrm{SrF}_{2} \mathrm{Na}(0.86-0.98 \mu \mathrm{m}), \mathrm{F}_{2}^{+} \mathrm{NaF}(0.87-1 \mu \mathrm{m}),\left(\mathrm{F}_{2}^{+}\right)_{\mathrm{A}} \mathrm{NaF} \mathrm{Li}(0.89-1.15 \mu \mathrm{m}),\left(F_{2}^{+}\right) \mathrm{NaF} \mathrm{Mg}^{2}$ $(1.05-1.27 \mu \mathrm{m})$ and $\left(F_{2}^{+}\right)_{\mathrm{H}}(1.52-1.76 \mu \mathrm{m})$. 
${ }^{[1]}$ D. MOUNIER, J.L. DOUALAN, S. GIRARD, J. MARGERIE AND K. MAZIGHI, Opt. Comm. 82 (1991) 314.

${ }^{[2]}$ H. EISELE, H.J. PAUS, J. WAGNER and M. LEDUC, J. Appl. Phys. 54 (1983) 4821.

${ }^{[3]}$ S. GIRARD, D. MOUNIER, J.L. DOUALAN and J. MARGERIE, Opt. Comm. 82 (1991) 321.

${ }^{[4]}$ W. GELLERMAN J. Phys. Chem. Solids 52 (1991) 249.

$\left(\mathrm{F}_{2}^{+}\right)^{-}$in $\mathrm{NaF}: \mathrm{Mg}^{2+}:$

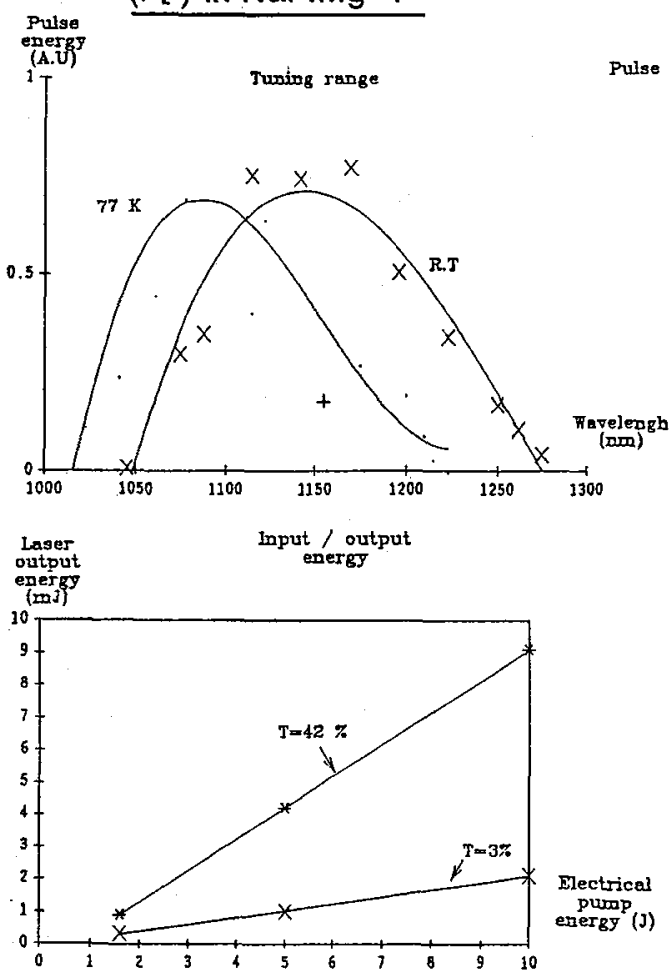

$\underline{\left(\mathrm{F}_{2}{ }^{+}\right)_{\mathrm{H}} \text { in } \mathrm{NaCl}: \mathrm{OH}^{-}}$

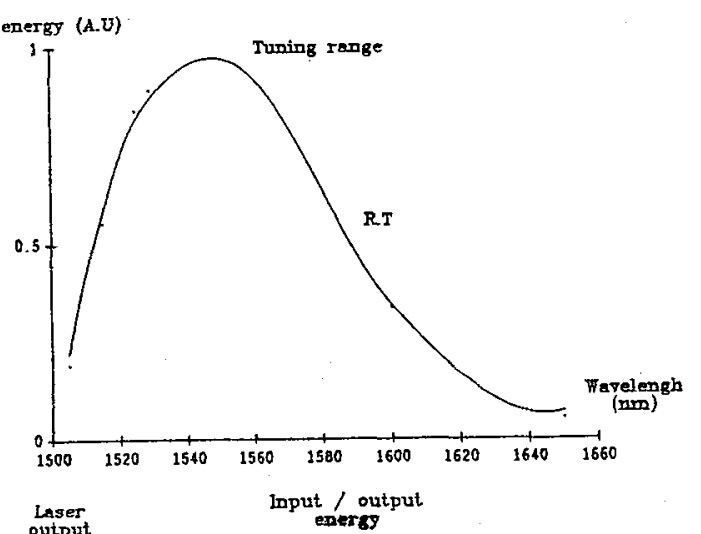

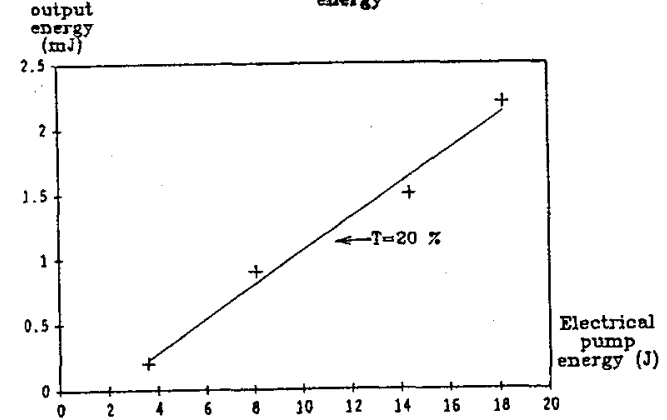

